\title{
Lietuvos gyventojų pasirengimo mokèti už atsinaujinančius energijos išteklius vertinimas
}

\section{Dalia Štreimikienė,}

\section{Ilona Ališauskaitè-Šeškienė}

Lietuvos energetikos institutas, Kompleksiniu energetikos tyrimu laboratorija, Breslaujos g. 3, LT-44403 Kaunas El.paštas: Dalia.Streimikiene@lei.lt; i.alisauskaite@gmail.com
Lietuvoje egzistuoja daugybé paramos atsinaujinantiems energijos ištekliams formų, tačiau jos visos nukreiptos i gamybos sektorių. Pasaulyje daugiausia dèmesio skiriama vartojimo sektoriui. Tiriami socialiniai naujų technologijų vertinimai bei technologiju priimtinumas visuomenèje, pasirengimas mokèti už klimato kaitos švelninimo priemones. Kadangi nuo $2013 \mathrm{~m}$. sausio $1 \mathrm{~d}$. Lietuvos gyventojai gali laisvai pasirinkti savo elektros energijos tiekèją bei taip paremti atsinaujinančių energijos išteklių panaudojimą, labai svarbu ištirti Lietuvos gyventojų pasirengimą mokèti už elektros energiją, pagamintą iš atsinaujinančių energijos išteklių, bei nustatyti pagrindinius veiksnius, lemiančius gyventojų pasirengimą mokèti už elektros energiją, pagamintą iš šių išteklių. Straipsnyje išnagrinèti pasirengimo mokèti už atsinaujinančius energijos išteklius tyrimai bei apibendrinti jų rezultatai, taip pat atliktas Lietuvos gyventoju pasirengimo mokèti už atsinaujinančius energijos išteklius vertinimas.

Raktažodžiai: atsinaujinantys energijos ištekliai, vartotojų pasirengimas mokèti, energetikos sektorius, vertinimas

\section{IVADAS}

Energetikos sektoriuje egzistuoja dvi pagrindinès šiltnamio dujų emisijų mažinimo priemonès tiek energijos gamybos, tiek vartojimo pusèje: energijos vartojimo efektyvumo ir atsinaujinančių energijos išteklių panaudojimo didinimas [1]. Energijos vartojimo efektyvumo didinimo priemonių diegimas taikant produktų inovacijas namų ūkiuose, pvz., mažųjų kogeneracinių jegainių i̇rengimas būstuose, Lietuvoje dar ankstyvas, nes tokios technologijos mūsų šalyje nèra paplitusios, ir gyventojai apie jas mažai žino. Be to, šios technologijos yra labai brangios. Dabartiniame etape aktualiau tirti Lietuvos gyventojų pasirengimą naudoti produktų inovacijas, pvz., atsinaujinančius energijos išteklius [2].
Lietuva yra i̇sipareigojusi padidinti atsinaujinančių energijos išteklių naudojimą tiek pagal ES, tiek pagal Lietuvos nacionalinius strateginius dokumentus. Privalomus tikslus dèl atsinaujinančių energijos išteklių naudojimo siekiant užtikrinti, kad iki 2020 m. ES mastu $20 \%$ bendrojo galutinio energijos suvartojimo sudarytų energija, gaunama iš atsinaujinančių energijos išteklių, nustato ES Direktyva dèl skatinimo naudoti atsinaujinančių išteklių energiją [3]. Nacionaliniame atsinaujinančiu išteklių energijos veiksmų plane nurodytas atsinaujinančių energijos ištekliu plètros tikslas - užtikrinti, kad atsinaujinančių energijos išteklių dalis, palyginti su šalies bendruoju galutiniu energijos suvartojimu, $2008 \mathrm{~m}$. sudariusi 15,3\%, $2020 \mathrm{~m}$. siektų ne mažiau $23 \%$ [4]. 
Nors Lietuvoje egzistuoja daugybė paramos atsinaujinantiems energijos ištekliams formų, tačiau dauguma jų nukreiptos i gamybos sektorių. Mūsų šalyje taikomi fiksuoti elektros energijos supirkimo iš atsinaujinančių energijos išteklių tarifai, kurie $2014 \mathrm{~m}$. II-IV ketvirtyje kinta nuo $0,22 \mathrm{Lt} / \mathrm{kWh}$ (vèjo ir hidrojėgainių pagaminama elektros energija) iki 0,69 Lt/kWh (saulès jègainių elektros energija) [5]. Taip pat skiriama tiesioginè parama atsinaujinantiems energijos išteklių projektams iš ES Struktūrinių fondų bei Lietuvos aplinkos apsaugos investicijų fondo. Tačiau energijos vartojimo sektoriuose Lietuvoje igyvendinamos atsinaujinančių energijos išteklių skatinimo priemonès yra nepakankamos.

Šiuo metu pasaulyje daug dèmesio skiriama elektros energijos vartojimui, taip pat socialiniam naujų technologijų vertinimui ir technologiju priimtinumo visuomeneje tyrimams bei pasirengimo mokèti už klimato kaitos švelninimo priemones vertinimui, bet Lietuvoje tokių tyrimų nèra atlikta [6]. Kadangi nuo 2013 m. sausio 1 d. Lietuvos gyventojai gali laisvai pasirinkti elektros energijos tiekeją ir taip paremti atsinaujinančių energijos ištekliu panaudojimą, svarbu ištirti Lietuvos gyventojų pasirengimą mokèti už elektros energiją, pagamintą iš atsinaujinančių energijos išteklių, bei nustatyti pagrindinius veiksnius, lemiančius gyventojų pasirengimą mokèti už elektros energiją, pagamintą iš šiu išteklių.

Straipsnio tikslas - atlikti pasirengimo mokèti už atsinaujinančius energijos išteklius tyrimus bei išnagrinèti jų rezultatus, ịvertinti Lietuvos gy- ventojų pasirengimą mokèti už atsinaujinančius energijos išteklius.

\section{PASIRENGIMO MOKĖTI UŽ ATSINAUJINANČIUS ENERGIJOS IŠTEKLIUS STUDIJŲ APŽVALGA}

Parenkant klimato kaitos švelninimo politikos priemones, svarbu ịvertinti išvengtą žalą dèl klimato kaitos švelninimo. Tačiau ją labai sunku ịvertinti piniginiais vienetais, todèl siūloma taikyti pasirengimo mokèti $(\mathrm{PM})$ vertinimo metodus. Ekonomistai mano, kad maksimali pinigų suma, kurią individai yra pasirengę arba pasiryžę skirti už aplinkos patogumus (įvertinus pajamų lygi ir kita), yra priimtinas ekonominès vertès ar „kainos" îvertinimas, atspindintis ittaką gerovès lygiui. 1 pav. pateikta Pasirengimo mokèti (PM) metodu klasifikavimo schema.

Kaip parodyta 1 pav., gyventojų PM gali būti ivvertintas pagal nustatytu preferencijų arba pareikštų preferencijų metodus $[6,7]$. Nustatytų preferencijų teorija, sukurta amerikiečiu ekonomisto P. Samuelson, siekiant iqvertinti politikos priemonių poveikị vartotojų elgsenai, vadovaujasi idejja, kad vartotojų preferencijos gali būti nustatytos atsižvelgiant $\mathfrak{i}$ jų pirkimo ípročius, analizuojant rinkos duomenis [8]. Hedonistinių kainų metodai yra pagrindiniai nustatytų preferencijų metodai rinkos duomenų analizès metodų grupèje. Hedonistinių kainų metodai vadovaujasi tuo, kad atitinkamų prekių kainos gali būti išskaidytos ị ịvairių prekès charakteristikų vertes, o pagal

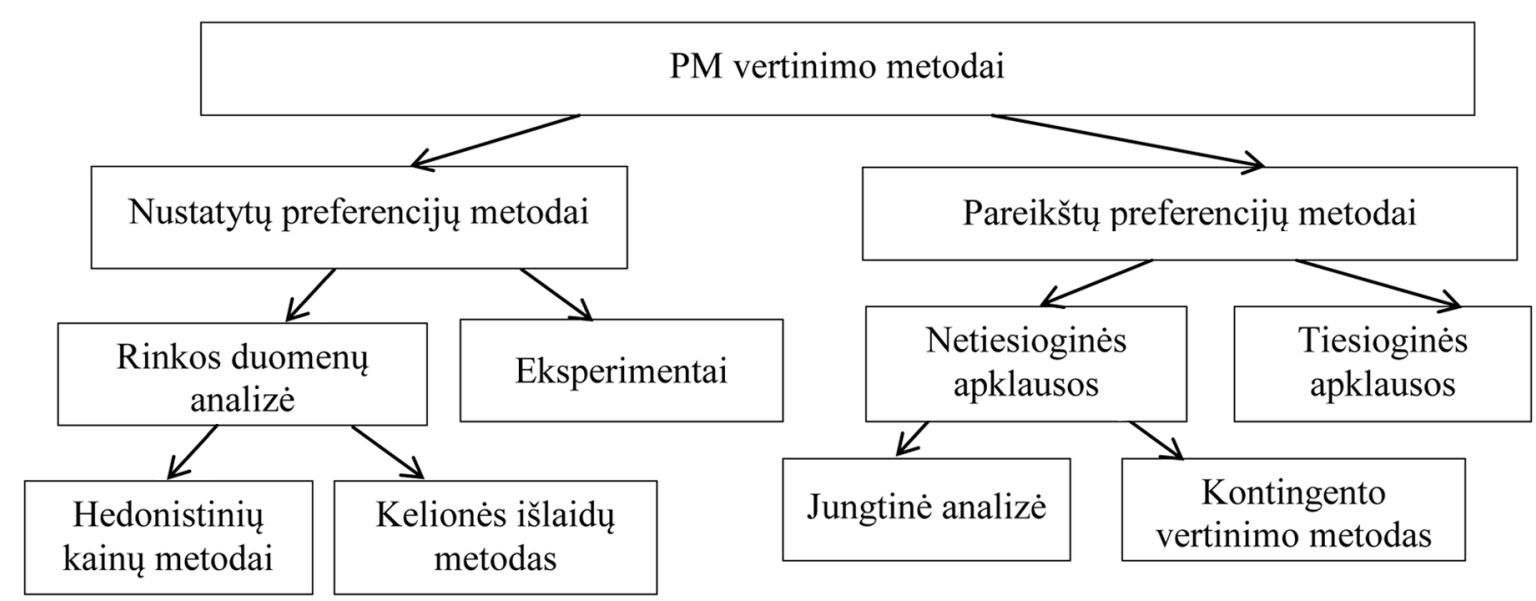

1 pav. PM vertinimo metodai 
jas nustatoma kaina gèrybių, kuriomis rinkoje nèra prekiaujama, pvz., švarus oras. Plačiausiai paplitęs šios grupès metodas - hedonistinis gyvenamųjų namų kainų metodas. Jis taikomas įvertinant aplinkos kokybę ir ịvairius vietovès specifinius veiksnius, pvz., transporto triukšmas, žaliụjų plotų gausa, oro kokybè ir kt., pagal nekilnojamojo turto kainų skirtumus [9].

Kelionès išlaidų arba Clawson metodas (angl. travel cost method) taip pat yra nustatytu preferenciju metodas, priskirtas rinkos duomenų analizès metodų grupei, dar vadinamas „rekreacijos paklausos modeliu" (angl. recreation demand mo$d e l$ ). Jis vadovaujasi vartotoju paklausos teorijos variantu, kuriame ypač išskiriama laiko vertè. Šis metodas buvo pritaikytas gamtiniams ištekliams (nacionalinių parkų, rezervatų ir pan.), kaip rekreacinès veiklos ištekliams, vertinti [10-12].

Eksperimentai yra priskiriami nustatytu preferencijų metodų grupei, nes, atliekant laboratorinius ir lauko eksperimentus, galima ivvertinti vartotojų preferencijas pagal jų sumodeliuotą pirkimo elgseną [13-14].

Pareikštų preferencijų metodai - tai apklausos. Jos skirstomos it tiesiogines, kurių metu gyventojai yra tiesiogiai apklausiami, kiek jie sutiktų mokèti už tam tikras gèrybes, ir netiesiogines apklausas, kurios vadovaujasi sudètingesniais PM nustatymo metodais. Pagrindiniai iš jų yra jungtinè analizė ir kontingento vertinimo metodas [15-16].

Jungtinė analizė yra vartotojų pareikštų preferencijų išaiškinimo technika, leidžianti nustatyti PM netiesioginiu būdu [15-19]. Respondentų prašoma suranguoti arba ịvertinti atskiras politikos priemonių alternatyvas jų neįvardijant, o tik vadovaujantis kriterijais, aprašančiais kiekvieną alternatyvą [20]. Vèliau respondentų pareikštos preferencijos pagal atskirus kriterijus yra išskaidomos taikant regresinę analizę ir nustatomos netiesiogiai respondentų pasirinktos politikos priemonès, pasižyminčios aukščiausiais vertinamų kriterijų balais.

Norint nustatyti, kokiai politikos priemonei gyventojai atiduoda pirmenybę, galima paprastos gyventoju apklausos metu tiesiogiai leisti respondentams pasirinkti priimtiną politikos priemonę. Toks tyrimas reikalauja mažai parengtinių tyrimų, nes užtenka pateikti tik politikos priemoniu pavadinimus, o respondentai turètų pasirinkti, patys įvertindami pateiktų klimato kaitos švelninimo priemonių savybes [18, 21-23].

Kontingento metodas yra sudètingesnis ir leidžia atlikti PM vertinimą pateikiant hipotetinius scenarijus respondentams. Scenarijai pateikiami tyrimo formatu, juose yra tam tikras apsikeitimas tarp naudingumo kiekio ir piniginès išraiškos. Surenkant atsakymus apie šiuos apsikeitimus, kuriose yra tam tikrų svyravimų tarp kainos ir naudingumo, galima nustatyti paklausos funkciją. Yra įvairių formų, kur gali būti pateiktas Kontingento vertinimo metodas, taip pat yra ir įvairių statistinių metodų, kuriais šie duomenys gali būti apdorojami. S. V. Ciriacy-Wantrup pirmasis apibrèžè kontingento metodą ir pasiūlè panaudoti kaip priemonę, skirtą įvertinti tų gèrybių kainą, pagal kurią reali rinka neegzistuoja. Kontingento metodas vadovaujasi apklausa, kurios metu siekiama nustatyti, kiek asmuo yra pasirengęs mokèti už viešą gèrybę ar aplinkos kokybès gerinimą, net jeigu jis tiesiogiai nesinaudoja tomis viešomis gèrybėmis ar aplinkos kokybės gerinimo rezultatais [24, 26, 27]. Kontingento metodo taikymas yra sudetingas, ilgai trunkantis ir brangus. Ši metodą paprastai taiko valstybinès institucijos, siekdamos ịvertinti, koki poveiki atskiri projektai turès aplinkai.

Lyginant nustatytų ir pareikštų preferenciju PM vertinimo metodus galima teigti, kad pasirengimą mokèti už atsinaujinančius energijos išteklius dèl klimato kaitos švelninimo priemonių, pvz., atsinaujinančių energijos išteklių skatinimo, specifikos, susijusios su globaliu klimato kaitos poveikiu, vertinti labiausiai yra tinkami pareikštų preferencijų metodai. Nustatytų preferencijų metodai, tokie kaip hedonistinių kainų, kelionès išlaidų bei laboratoriniai eksperimentai, yra labiau tinkami vertinant aplinkos taršos mažinimą, gamtinès aplinkos kokybès gerinimo naudą, nes siejasi su konkrečia vietove. Klimato kaita yra globalus reiškinys, ir hedonistinès nekilnojamo turto kainos bei kelionès išlaidų metodas ar laboratorinis eksperimentas negali ịvertinti globalių klimato kaitos mažinimo pokyčių naudos konkrečioje vietoveje. Todèl ekonomistai klimato kaitos švelninimo politikos naudą siūlo vertinti kaip kolektyvinį visuomenès narių PM už klimato stabilizavimą ir daugeliu atveju taiko tik pareikštų preferencijų metodus [28]. 
Pareikštų preferencijų metodai, pvz., tiesioginès arba netiesioginès gyventojų apklausos, leidžia ịvertinti gyventojų PM moketi už sulètejusią klimato kaitą, išvengtą žalą dèl anomalių temperatūros svyravimų, kritulių, sausros, ekstremalių gamtos reiškinių, kuriuos sąlygoja šiltnamio dujų koncentracijos atmosferoje augimas [29].

Didžioji dalis išnagrinètų studijų dèl PM už priemones klimato kaitai stabilizuoti buvo atliktos pastaraji dešimtmeti ir visos jos atliktos po 1998 m. PM studijos apèmè bendrą klimato kaitos stabilizavimo politiką, investavimo ị žaliąją energiją, temperatūros pokyčių mažinimą, energijos taupymą bei anglies dvideginio sugaudymo mechanizmus [22, 30-43]. Visose nagrinejjamose studijose PM už klimato kaitos stabilizavimą buvo i̇vertintas taikant kontingento vertinimo metodą ir tiesiogines gyventojų apklausas dèl metodų privalumų, kurie buvo aptarti anksčiau $[31,44]$.

Analizuotose studijose buvo nustatyti tokie svarbiausi aiškinamieji kintamieji, turintys itakos PM už klimato kaitos stabilizavimo politiką, - tai lytis, išsilavinimo lygis, prisiimtas atsakomybès lygis, numatytas temperatūros padidejjimas, mokesčių mechanizmai ir klimato kaitos švelninimo politikos rezultatų išmanymas [30, 40, 45-47].

Didžioji dalis studijų nustato PM apimtis kaip kasmetị namų ūkio PM doleriais. Išnagrinettose studijose PM kinta nuo 5,7 JAV dol. iki $3623 \mathrm{JAV}$ dol. per metus [30, 38]. Atmetus išsišokančias reikšmes, vidutinè reikšmė siekia 167 JAV dol. per metus ir kinta nuo 22 JAV dol. iki 437 JAV dol. per metus. Tokios kitimo ribos parodo, kad būtina atlikti naujus tyrimus, leidžiančius tiksliau nustatyti bendrus aiškinamuosius kintamuosius, ịvertinant PM skaitines reikšmes. Išnagrinètos $\mathrm{PM}$ vertinimo studijos skiriasi atliktų apklausų imtimis, tyrimo laikotarpiu ir vieta. Didžioji dalis apklausų pateikia vidutines metines PM vertes, tačiau kitos studijos išskiria PM keleriems metams, dar kitos studijos neidentifikuoja jokios laiko ribos, pateikdamos vieną bendrą PM ịvertinimą [32, 48].

Amžius ir kiti demografiniai bei socialiniai-ekonominiai kintamieji (pajamos, socialinis statusas, užimtumas ir kt.) yra labai svarbūs nagrinejjant studijų gautus rezultatus [30-32, 40,
44-45]. 14 iš 28 studijų buvo atliktos JAV [4041, 45, 49]. Kitos studijos atspindi PM skirtingose Europos ir Azijos valstybèse. F. Carlsson su kolegomis atliko tokias pačias apklausas trijuose skirtinguose kontinentuose, kad nustatytų realius skirtumus įvertinant $\mathrm{PM}$ dèl $\mathrm{CO}_{2}$ mažinimo tarp amerikiečių, azijiečių, ir europiečių [50]. Taigi, demografiniai, ekonominiai, kultūriniai ir geografiniai skirtumai, ịvertinti apklausose, bei pasiūlytos klimato kaitos politikos priemonès (pvz., vietinès, nacionalinès, globalios priemonès klimato kaitai švelninti) leidžia paaiškinti didelius PM įvertinimo skirtumus tarp atskiru studijų.

Lietuvoje nèra atlikta jokių studijų, skirtų ìvertinti Lietuvos namų ūkių PM už atsinaujinančius energijos išteklius, energijos efektyvumo didinimo priemones ar kitas klimato kaitos švelninimo priemones. PM tyrimai leidžia nustatyti ekonomiškai pagrisstas paramos atsinaujinantiems energijos ištekliams priemones, nes, kaip minèta anksčiau, leidžia ịvertinti išorinę naudą dèl atsinaujinančių energijos išteklių panaudojimo arba išvengtą žalą dèl klimato kaitos. Šiuo metu Lietuvoje taikomos paramos atsinaujinantiems energijos ištekliams priemonès, už kurias sumoka mokesčių mokètojai, nèra nustatytos pagal Lietuvos gyventojų PM už elektros energiją, pagamintą iš atsinaujinančių energijos išteklių.

\section{LIETUVOS GYVENTOJŲ PM UŽ ATSINAUJINANČIUS ENERGIJOS IŠTEKLIUS VERTINIMAS}

Siekiant atlikti gyventojų pasirengimo mokèti už atsinaujinančius energijos išteklius tyrimą, pasinaudota kitų šalių tyrimų pavyzdžiu. Atlikta gyventojų apklausa, sudarius kontrolinę respondentų grupę, ir pasirinktas tiesioginis pareikštų preferencijų PM nustatymo būdas, nereikalaujantis didelių išlaidų ir sudètingų hipotetinių scenarijų formavimo.

\section{Tyrimo aprašymas}

Atlikta literatūros analizè parodè, kad visuomenès informuotumas, informacijos prieinamumas, požiūris i aplinkosaugos problemas ir susirūpinimas aplinka yra svarbūs aspektai, turintys ịtakos PM už atsinaujinančius energijos išteklius. 
Atsižvelgus ị anksčiau kitose šalyse atliktų tyrimų eigą, buvo atliktos dvi apklausos. Tuo tikslu parengtos dvi apklausos anketos. $2013 \mathrm{~m}$. kovo $23 \mathrm{~d}$. - birželio $23 \mathrm{~d}$. atliktos 2 kontrolinès grupès apklausos.

Pirmajame laiške respondentai buvo kviečiami dalyvauti tyrime ir užpildyti pirmąją (pirminę) anketą. Gavus atsakymus su užpildytomis pirminemis anketomis, buvo sudaryta kontrolinẻ grupe iš 100 respondentų, iš jų 99 teisingai užpildè anketą. Buvo parinkti tik tie respondentai, kurie atsakè i pirminès anketos klausimus ir sutiko dalyvauti tyrime bei atsakyti $\mathfrak{i}$ antrosios anketos klausimus po pateiktos papildomos informacijos apie atsinaujinančių energijos išteklių naudą, jų skatinimo priemones ir galimybę rinktis elektros energijos tiekejją.

Kontrolinès grupès dalyviams buvo pateikti pirmosios anketos klausimai: ar jie yra girdèję apie elektros energiją, pagamintą iš atsinaujinančių energijos išteklių, ar jie tiki globaliu klimato atšilimu ir kas, jų manymu, yra atsakingas už klimato kaitos švelninimą. Šių trijų klausimų iki informacijos apie atsinaujinančius energijos išteklius pateikimo pagrindinis tikslas buvo nustatyti gyventojų informuotumą apie atsinaujinančius energijos išteklius ir jų susirūpinimą klimato kaita bei požiūrị i klimato kaitos švelninimo politiką bei jos ịgyvendinimą.

PM už elektros energiją, pagamintą iš atsinaujinančių energijos išteklių, iki ir po informacijos pateikimo buvo įvertintas uždavus du klausimus:

1. Ar sutiktumète moketi papildomai $12 \mathrm{Lt}$ per mènesį už elektros energiją, kad $5 \%$ jūsų suvartojamos elektros energijos būtų pagaminta iš atsinaujinančių energijos išteklių?

2. Kiek sutiktumète mokèti papildomai per ménesị už elektros energiją, pagamintą iš atsinaujinančių energijos išsteklių, kad ji sudarytų $10 \%$ jūsų suvartojamos elektros energijos?

Pasirinkta $5 \%$ elektros energijos iš atsinaujinančių energijos išteklių dalis, nes iki Ignalinos $\mathrm{AE}$ uždarymo elektros energijos, pagamintos iš atsinaujinančių šaltinių, dalis irgi buvo apie $5 \%$. Kadangi aukščiausia elektros energijos supirkimo kaina iš atsinaujinančių energijos išteklių Lietuvoje $2012 \mathrm{~m}$. sieke $1,66 \mathrm{Lt} / \mathrm{kWh}$ (tais metais buvo rengiamas tyrimas bei ruošiama jo igyvendinimo metodika), o vidutinis elektros energijos suvarto- jimas Lietuvos namų ūkiuose per ménesį yra apie $150 \mathrm{kWh}$, todèl aukščiausia kaina, kurią gyventojai turètų mokèti už $5 \%$ elektros energijos, pagamintos iš atsinaujinančiu energijos išteklių, sudarytų $12 \mathrm{Lt}$ per mènesi $(7,5 \mathrm{kWh}$ elektros energijos iš atsinaujinančiu energijos išteklių).

Antruoju klausimu buvo siekiama išsiaiškinti, kiek patys gyventojai papildomai sutiktų mokèti per ménesi už elektros energiją, kad ji sudarytų $10 \%$ suvartojamos elektros energijos. Ši procentinè dalis pasirinkta, nes Lietuva prisièmusi įsipareigojimą iki 2020 m. $21 \%$ elektros energijos pagaminti iš atsinaujinančių energijos išteklių, o $2010 \mathrm{~m}$. nustatytas tikslas - $10 \%$ - nebuvo pasiektas.

Anksčiau paminèti du klausimai, skirti nustatyti, kokią įtaką PM turi informuotumas apie atsinaujinančius energijos išteklius ir jų naudą, bei kaip ši informacija veikia gyventojų susirūpinimą aplinka, požiūrị i klimato kaitos politiką, jos finansavimą, igyvendinimo priemones ir atsakingas institucijas.

Antrosios apklausos metu po kryptingos informacijos apie atsinaujinančius energijos išteklius pateikimo respondentams buvo užduoti tie patys klausimai apie PM už elektros energiją iš atsinaujinančių energijos išteklių ir klausiama, kas turètų padengti elektros energijos, pagamintos iš atsinaujinančių energijos išteklių, išlaidas ir kokios yra pagrindinès priežastys, skatinančios bei stabdančios gyventojus mokèti už elektros energiją, pagamintą iš atsinaujinančių energijos išteklių. Papildomai respondentų buvo teiraujamasi, ar jie sužinojo ką nors naujo iš pateiktos kryptingos informacijos apie atsinaujinančius energijos išteklius. Taip pat kiekvienos apklausos metu buvo surinkta kontrolinès grupès respondentu demografinè, socialinè-ekonominé informacija apie amžių, lyti, pajamas, užimtumą.

PM už elektros energiją, pagamintą iš atsinaujinančių energijos išteklių, tyrimas Lietuvoje buvo atliktas dviem etapais. Pirmajame etape buvo palygintas respondentų PM už elektros energiją, pagamintą iš atsinaujinančių energijos išteklių, prieš ir po informacijos pateikimo, pritaikius neparametrinę regresiją ir branduolio tankio vidurkio vertinimus.

Siekiant ištirti statistinius ryšius tarp PM ir skirtingų respondentų charakteristikų bei požiūrių, pritaikyta daugiamate neparametrinè regresija 
siekiant pamatyti, kurie iš nagrinėjamų veiksnių (užimtumas, lytis, pajamos, amžius, informuotumas ir kt.) gali prisidèti teigiamai ir kurie neigiamai prie vartotojų pasirengimo mokèti už elektrą, pagamintą iš atsinaujinančių energijos išteklių. Buvo taikoma viena iš dvinarès logistinès regresijos alternatyvu - probit regresija ir branduolio tankio vidurkio vertinimas, nors apklausos rezultatams apdoroti buvo galima naudoti ir kitus matematinius metodus, tačiau pasirinkti vieni paprasčiausių ir populiariausių.

Šiuolaikinèje duomenų analizèje taikoma daugybė neparametrinių metodų, skirtų statistiškai vertinti daugiamačių atsitiktinių dydžių pasiskirstymo tankį. Ypač plačiai paplitę branduoliniai neparametriniai įvertinimai. Analizuojant ryšius tarp faktorių $X$ ir atsako $Y$ susidaro situacija, kai regresijos funkciją $f(x)$ sudètinga išreikšti parametriškai. Todèl taikomi funkcijos $f(x)$ neparametriniai regresijos kreivès įverčiai arba realūs $Y$ duomenys tam tikru būdu suglodinami. Branduolinių ịverčių konstrukcijos svarbiausias elementas yra glodinimo plotis.

Antrajame etape atlikta daugiamate atitikties analizè (angl. Multiply correspondence analysis) siekiant nustatyti demografinių bei kitų veiksnių ittaką PM, analizuojant antrosios apklausos rezultatus.

Straipsnyje pritaikyta daugiamatè atitikties analizè yra dimensijų mažinimo metodas, igalinantis analizuoti ryšius tarp daugelio skirtingų (kategorinių ir kiekybinių) dimensijų rodiklių. Dimensijų sumažinimo algoritmai yra taikomi norint aiškiai matyti sąryšius daugiadimensiniuose ir kategoriniuose duomenyse. Daugiamatès atitikties analizès procedūros leidžia atlikti statistines kategorinių duomenų operacijas. Jos sudaro sąlygas pritaikyti optimalaus skaliavimo procedūras ir suteikti kategoriniams duomenims atskaitos tašką bei matus.

\section{Gautų rezultatų aptarimas}

Tyrimo metu buvo siekiama nustatyti gyventojų PM už elektros energiją, pagamintą iš atsinaujinančių energijos ištekliu, ir pagrindinius veiksnius, turinčius įtakos PM. 1 lentelèje pateikti apibendrinti tyrimo rezultatai.

Kaip parodyta 1 lenteleje, apie $86 \%$ respondentų amžius buvo ne mažesnis kaip 35 metai. Apie $72 \%$ respondentų turejo aukštąj išsilavini- mą. Pagal užimtumą, po lygiai respondentų dirbo viešajame ir privačiame sektoriuose (atitinkamai 33 ir $34 \%$ ), o po $16 \%$ respondentų buvo savarankiškai dirbantys ir nedirbantys. $10 \%$ respondentų ménesinès pajamos sieké per $3000 \mathrm{Lt}$, o $10 \%$ respondentų gyveno namų ùkiuose, kuriuose ìsikūrę mažiausiai 5 šeimos nariai. Didžioji dalis respondentų (81\%) ir iki informacijos pateikimo buvo girdeję apie elektros energiją, pagamintą iš atsinaujinančių energijos išteklių. Tačiau net $46 \%$ respondentų pareiške, kad jie nelaiko globalaus atšilimo svarbia problema. Apklausa parodè, kad $36 \%$ respondentų laiko atsakingais už klimato kaitos švelninimą individus, naudojančius energiją, $26 \%$ respondentų - energiją tiekiančias kompanijas. $44 \%$ respondentų daugiau mokèti už elektros energiją, pagamintą iš atsinaujinančių energijos išteklių, skatina aplinkosauginès problemos, tarp jų - klimato kaita. Tačiau daugeliui respondentų (31\%) ekonominès priežastys (per brangu) yra pagrindinès, stabdančios pasirengimą mokèti už elektros energiją, pagamintą iš atsinaujinančių energijos išteklių.

Apklausos rezultatai po informacijos pateikimo atskleide, kad respondentų gauta informacija turejjo teigiamos įtakos jų nusiteikimui mokèti už atsinaujinančius energijos išteklius. Dalis respondentų, kurie sutiko mokèti papildomai po $12 \mathrm{Lt} /$ mèn. už elektros energiją, pagamintą iš atsinaujinančių energijos išteklių, išaugo nuo 50 \% (iki informacijos pateikimo) iki $67 \%$ (pateikus informaciją).

Respondentų apklausos metu buvo klausiama, kokią sumą jie yra pasirengę sumokèti už tai, kad jų suvartojamą elektros energiją $10 \%$ sudarytų elektros energija, pagaminta iš atsinaujinančių energijos išteklių. Vidutinis PM dydis išaugo nuo 5,2 iki 6,5 Lt. Reikia pabrèžti, kad atsakymų pasiskirstymas išliko panašus, o variacijos koeficientas po informacinio seminaro nukrito nuo 100 iki $85 \%$. Taigi, respondentu atsakymai po informacinio seminaro labiau išsiskyrè. $45 \%$ respondentų konstatavo, kad jie gavo papildomų žinių apie elektros energiją, pagamintą iš atsinaujinančių energijos išteklių, ir jos naudą kovojant su klimato kaita. 46 \% respondentų nurodé, kad jie yra pasiruošę pasidalyti gauta informacija su draugais ir diskutuoti apie elektros energiją, pagamintą iš atsinaujinančių energijos išteklių. 
1 lentelè. Tyrimo rezultatų apibendrinimas

$\mathrm{N}=99$

\begin{tabular}{|c|c|c|}
\hline Kintamieji & Lygiai & Procentai \\
\hline \multirow{2}{*}{$\begin{array}{l}\text { Ar esate girdèjęs apie elektros energiją iš atsinauji- } \\
\text { nančių energijos išteklių? }\end{array}$} & $0-$ ne & 19,2 \\
\hline & $1-$ taip & 80,8 \\
\hline \multirow{2}{*}{ Ar tikite globaliu klimato atšilimu? } & $0-$ ne & 45,5 \\
\hline & $1-$ taip & 54,5 \\
\hline \multirow{5}{*}{ Kas atsakingas už klimato kaitos švelninimą? } & 1 - visi ir kiekvienas & 5,1 \\
\hline & $2-$ valstybè & 13,1 \\
\hline & 3 - individai, naudojantys energiją & 36,4 \\
\hline & 4 - energijos tiekimo kompanijos & 26,3 \\
\hline & $0-$ nežinau & 19,2 \\
\hline \multirow{3}{*}{$\begin{array}{l}\text { Ar sutiktumète mokèti papildomai } 12 \mathrm{Lt} / \text { mèn. už } \\
\text { elektros energiją, kad } 5 \% \text { jūsų suvartojamos elektros } \\
\text { energijos būtų pagaminta iš atsinaujinančiu energijos } \\
\text { išteklių? (prieš informacini seminarq) }\end{array}$} & $0-$ ne & 29,3 \\
\hline & $1-$ taip & 49,5 \\
\hline & nežinau & 21,2 \\
\hline \multirow{2}{*}{$\begin{array}{l}\text { Ar sutiktumète mokèti papildomai } 12 \text { Lt/mèn. už } \\
\text { elektros energiją, kad } 5 \% \text { jūsų suvartojamos elektros } \\
\text { energijos būtų pagaminta iš atsinaujinančiu energijos } \\
\text { išteklių? (po informacinio seminaro) }\end{array}$} & $0-$ ne & 33,3 \\
\hline & 1 - taip & 66,7 \\
\hline
\end{tabular}

Kiek sutiktumète mokèti papildomai per mènesį už elektros energiją iš atsinaujinančių energijos išteklių, kad ji sudarytų $10 \%$ jūsų vartojamos elektros energividurkis (SD) $5,2(5,2)$ jos? (prieš informacini seminarq)

Kiek sutiktumète mokèti papildomai per mènesį už elektros energiją iš atsinaujinančių energijos išteklių, kad ji sudarytu 10 \% jūsų vartojamos elektros energijos? (po informacinio seminaro)

\begin{tabular}{|c|c|c|}
\hline \multirow{5}{*}{$\begin{array}{l}\text { Kas turètų padengti elektros energijos, pagamintos iš } \\
\text { atsinaujinančių energijos ištekliu, išlaidas? }\end{array}$} & $1-$ visi & 15,2 \\
\hline & $2-$ Vyriausybè & 15,2 \\
\hline & 3 - individualūs energijos vartotojai & 33,3 \\
\hline & 4 - energijos tiekimo kompanijos & 25,3 \\
\hline & $0-$ nežinau & 11,1 \\
\hline \multirow{5}{*}{$\begin{array}{c}\text { Kokios yra pagrindinès priežastys, skatinančios jus } \\
\text { mokèti už elektros energiją, pagamintą iš atsinau- } \\
\text { jinančių energijos išteklių? }\end{array}$} & 1 - skatina ekonomikos augimą & 11,1 \\
\hline & $\begin{array}{l}2 \text { - mažina priklausomumą nuo } \\
\text { energijos importo }\end{array}$ & 14,1 \\
\hline & 3 - mažina šiltnamio dujų emisijas & 16,2 \\
\hline & 4 - teigiama įtaka aplinkai & 27,3 \\
\hline & $0-$ nežinau & 31,3 \\
\hline \multirow{5}{*}{$\begin{array}{l}\text { Kokios yra pagrindinės priežastys, stabdančios jūsų } \\
\text { pasirengimą mokèti už elektros energiją, pagamintą } \\
\text { iš atsinaujinančių energijos išteklių? }\end{array}$} & 1 - stabdo ekonomikos augimą & 21,2 \\
\hline & 2 - tai Vyriausybès atsakomybè & 7,1 \\
\hline & 3 - tai per brangu & 31,3 \\
\hline & 4 - tai išteklių švaistymas & 11,1 \\
\hline & $0-$ nežinau & 29,3 \\
\hline \multirow{4}{*}{ Ar jūs sužinojote ką nors naujo seminaro metu? } & $1-$ ne & 12,1 \\
\hline & 2 - truputi & 33,3 \\
\hline & 3 -daug & 20,2 \\
\hline & 0 - nežinau & 34,3 \\
\hline \multirow{2}{*}{$\begin{array}{l}\text { Ar jūs aptarsite elektros energijos, pagamintos iš } \\
\text { atsinaujinančių energijos ištekliu, skatinimo problemą } \\
\text { su draugais? }\end{array}$} & $0-$ ne & 54,5 \\
\hline & 1 - taip & 45,5 \\
\hline
\end{tabular}




\begin{tabular}{|c|c|c|}
\hline 1 lentelè. Tęsinys & & \\
\hline Kintamieji & Lygiai & Procentai \\
\hline \multirow{5}{*}{ Užimtumas } & 1 - dirbantis savarankiškai & 16,2 \\
\hline & 2 - dirbantis viešajame sektoriuje & 34,3 \\
\hline & 3 - dirbantis privačiame sektoriuje & 33,3 \\
\hline & $4-$ studentas & 6,1 \\
\hline & $5-$ pensininkas & 10,1 \\
\hline \multirow{3}{*}{ Išsilavinimas } & 1 - vidurinis & 9,1 \\
\hline & 2 - aukštesnysis & 19,2 \\
\hline & 3 - aukštasis & 71,7 \\
\hline \multirow{5}{*}{ Pajamos per mènesi } & $1-\mathrm{iki} 1000 \mathrm{Lt}$ & 21,2 \\
\hline & $2-1001-2000 \mathrm{Lt}$ & 32,3 \\
\hline & $3-2001-3000 \mathrm{Lt}$ & 36,4 \\
\hline & $4-3001-4000 \mathrm{Lt}$ & 5,1 \\
\hline & $5-\operatorname{per} 4000 \mathrm{Lt}$ & 5,1 \\
\hline \multirow{5}{*}{ Amžius } & $1-\mathrm{iki} 23$ & 4,0 \\
\hline & $2-23-34$ & 10,1 \\
\hline & $3-35-44$ & 37,4 \\
\hline & $4-45-65$ & 29,3 \\
\hline & $5-\operatorname{per} 65$ & 19,2 \\
\hline \multirow{5}{*}{ Namų ūkio dydis } & $1-1$ asmuo & 22,2 \\
\hline & $2-2$ asmenys & 37,4 \\
\hline & $3-3-4$ asmenys & 30,3 \\
\hline & $4-5$ asmenys & 8,1 \\
\hline & 5 - daugiau 5 asmenu & 2,0 \\
\hline \multirow{2}{*}{ Lytis } & $0-$ vyras & 68,7 \\
\hline & 1 - moteris & 31,3 \\
\hline
\end{tabular}

Šaltinis: sudaryta autorių.

2 pav. pavaizduoti PM branduolio tankio pasiskirstymai iki informacijos pateikimo ir ją pateikus. $X$ ašyje nurodytos $P M$ reikšmès, o $Y$ ašyje - apklausos metu nustatytų PM reikšmių pasiskirstymų branduolio tankiai iki ir po informacijos pateikimo. Ištisiné linija parodo PM pasiskirstymo branduolio tankị iki informacijos pateikimo, o brūkšniné linija - pateikus informaciją.

Kaip parodyta 2 pav., branduolio įvertinimai PM už atsinaujinančius energijos išteklius išaugo po informacinès kampanijos. Iki informacijos pateikimo didžioji dalis respondentų nenorejo papildomai moketti už atsinaujinančius energijos išteklius (tarp atsakymų išryškejo viena modalinè reikšmè - 0), tačiau vidutinè $\mathrm{PM}$ verté siekè 5,5 Lt. Tačiau po informacijos pateikimo išryškèjo bi modalinis PM pasiskirstymas tarp respondentų, kai modalinès reikšmès siekè 0 ir $12 \mathrm{Lt}$, o $\mathrm{PM}$ vidutinè reikšmė išaugo iki 6,5 Lt. Tai rodo, kad Lietuvos gyventojai sutinka daugiau mokèti už elektros energiją, pagamintą iš atsinaujinančių energijos išteklių, siekiant užtikrinti $10 \%$ elektros energijos iš atsinaujinančių energijos išteklių. $2013 \mathrm{~m}$. atliktame tyrime gyventojai nurodè, kad sutinka mokèti žymiai mažiau nei

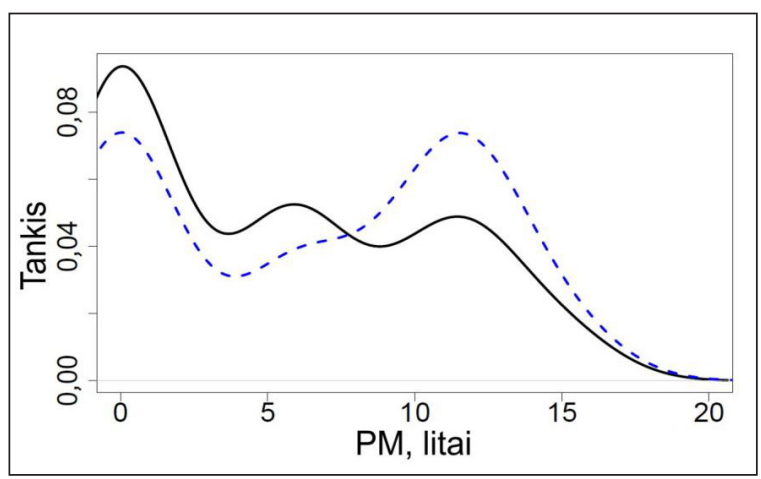

2 pav. PM už elektros energiją, pagamintą iš atsinaujinančių energijos išteklių, branduolio tankiai iki (vientisa kreivè) ir po (brūkšninė kreivè) informacijos pateikimo 
tuo metu taikytos aukščiausios subsidijos elektros energijai iš atsinaujinančių energijos išteklių pagaminti (1,66 Lt/kWh). Pagal gyventojų pasirengimo mokèti už elektros energiją, pagamintą iš atsinaujinančių energijos išteklių, tyrimo rezultatus, fiksuotos elektros energijos supirkimo kainos už elektros energiją, pagamintą iš atsinaujinančių energijos išteklių, neturètų viršyti $0,85 \mathrm{Lt} / \mathrm{kWh}$.

Siekiant nustatyti, ar empirinis kumuliacinis PM už elektros energiją iš atsinaujinančių energijos ištekliu pasiskirstymas labai skiriasi iki ir po informacijos pateikimo, buvo pritaikytas neparametrinis Kolmogorovo-Smirnovo testas. Jis taikomas hipotezei apie kiekybinio reiškinio požymio reikšmių skirstinio suderinamumą su normaliuoju skirstiniu tikrinti. Kolmogorovo-Smirnovo testas parodé, kad p vertè siekia 0,103 , t. y. hipotezé, kad PM po informacijos pateikimo buvo ne mažesnis nei iki informacijos pateikimo, turètų būti atmesta su $5 \%$ tikimybès paklaida, nors atmetimas su $10 \%$ tikimybe būtu nepakankamai tikslus tokioms mažoms imtims.

Taigi, atlikta analizè neleidžia daryti pagrịstų išvadų, kad egzistuoja ryšys tarp informacijos pateikimo ir pakitusio PM už elektros energiją, pagamintą iš atsinaujinančių energijos išteklių (po gautos informacijos). Todèl būtina apskaičiuoti paprastąją regresiją ir probit regresiją su apribojimu iki 0 , siekiant nustatyti ryši tarp PM iki ir po informacinio seminaro individualiu lygiu. Abi regresijos (tiek paprastoji, tiek probit) parodè, kad respondentai, kurie turèjo aukštesnius PM lygius iki informacijos gavimo ir po, buvo pasirengę mokèti net daugiau. Galima apibendrinti, kad kiekvienas litas, viršijantis vidutinę PM reikšmę iki informacijos pateikimo, padidino PM po informacinès kampanijos $0,72 \mathrm{Lt}$ pagal mažiausiųjų kvadratų metodą $(\mathrm{p}<.000)$ arba net $0,98 \mathrm{Lt}$ pagal probit regresiją $(\mathrm{p}<.000)$. 2 lenteleje pateikti pagrindiniai regresinès analizès parametrai.

Galima daryti išvadą, kad informacijos pateikimas padidino vidutinị bendrą respondentų PM už elektros energiją, pagamintą iš atsinaujinančių energijos išteklių. Be to, respondentai yra linkę mokèti daugiau už elektros energiją, pagamintą iš atsinaujinančių energijos išteklių, po informacinès kampanijos. Todèl gyventoju informavimas gali būti laikomas svarbia priemone siekiant paskatinti Lietuvoje efektyvesni atsinaujinančių energijos išteklių naudojimą. Kita vertus, iš atlikto tyrimo rezultatų negalima daryti išvados, kad Lietuvoje trūksta informacijos apie atsinaujinančius energijos išteklius.

Siekiant nustatyti ryšius tarp PM ir demografinių bei socialinių-ekonominių kintamųjų, pritaikyta neparametrinè regresija [53]. Išanalizuoti PM po informacijos pateikimo ir ji lemiantys veiksniai. Atlikta analizè parodè, kad užimtumas ir išsilavinimas sąlygoja žemą priklausomo kintamojo (PM) kitimą. Savarankiškai dirbantys respondentai demonstravo didžiausią $\mathrm{PM}$, palyginti su kitais respondentais. Be to, privačiame

2 lentelè. Regresijos modeliai, aprašantys ryšius tarp PM iki informacinio seminaro ir PM po informacinio seminaro

\begin{tabular}{cccc}
\hline & Koeficientas & Standartinè paklaida & t reikšmé \\
\hline & Paprastoji regresija & \\
\hline Laisvasis narys & 2,79809 & 0,56807 & $4,926^{* * *}$ \\
\hline PM iki informacinio seminaro & 0,72155 & 0,07758 & $9,301^{* * *}$ \\
\hline & & $\mathrm{R} 2$ & 0,47140 \\
\hline Laisvasis narys & Probit regresija & \\
\hline Logaritminis standartinis nuokrypis & $-0,1089$ & 0,919759 & $-0,1184$ \\
\hline PM iki informacinio seminaro & 1,75026 & 0,087176 & $20,0773^{* * *}$ \\
\hline Logaritminė tikimybe & 0,97889 & 0,118064 & $8,2912^{* * *}$ \\
\hline
\end{tabular}

Pastaba: PM iki informacinio seminaro yra nepriklausomas kintamasis;

PM po informacinio seminaro yra priklausomas kintamasis;

*** - žymi $1 \%$ statistinį reikšmingumą. 
sektoriuje dirbantys bei pensininkai taip pat demonstravo didesni PM, palyginti su dirbančiais viešajame sektoriuje bei studentais. Tyrimas parodé, kad aukštąj išsilavinimą turintys respondentai atskleidè didesni PM už elektros energiją, pagamintą iš atsinaujinančių energijos išteklių, o gaunantys didesnes pajamas pareiškè pasirengę daugiau mokèti ir už elektros energiją, pagamintą iš atsinaujinančių energijos išteklių.

Apdorojant apklausos rezultatus buvo pritaikyta daugiamatès atitikties analizė siekiant nustatyti ryšius tarp kokybinių kintamųjų ir PM, išreikšto kiekybiniu dydžiu [53]. Išskirtos trys kintamųjų grupès. Pirmajai grupei priskirti kategoriniai kintamieji, aprašantys respondentų požiūrị i i energijos vartojimą bei atsinaujinančių energijos išteklių skatinimo politiką. I antrają grupę buvo suskirstyti kategoriniai kintamieji, aprašantys respondentų demografines charakteristikas. Trečiajai grupei priskirti papildomi kiekybiniai kintamieji, t. y. PM už elektros energiją, pagamintą iš atsinaujinančių energijos išteklių. Šiame etape buvo naudojami respondentų apklausos po informacijos pateikimo duomenys.

Tyrimo rezultatai parodè, kad respondentai, kurie gavo papildomos informacijos seminaro metu, ịsitikino, kad Vyriausybè yra atsakinga už išlaidų, skirtų atsinaujinantiems energijos ištekliams skatinti, padengimą ir tai yra viena pagrindinių priežasčių, stabdančių respondentų PM už atsinaujinančius energijos išteklius. Be to, šie respondentai mažiau yra linkę aptarti atsinaujinančios elektros energijos ir jos paramos problemas su draugais, nes, jų manymu, atsinaujinančių energijos išteklių skatinimas yra Vyriausybés problema. Be to, respondentai, pasižymintys didesniu PM, galvoja, kad atsinaujinančius energijos išteklius reiktų skatinti dèl jų teigiamo aplinkosauginio poveikio bei šiltnamio dujų emisijų mažinimo, ir yra įsitikinę, kad atsinaujinančių energijos išteklių skatinimo naštą turètu prisiimti visi energijos vartotojai. Tačiau šie respondentai yra susirūpinę, kad dèl papildomų išlaidų, skirtų skatinti atsinaujinančius energijos išteklius, brangs elektros energija, o tai turès neigiamos įtakos šalies ekonomikos augimui. Galima daryti išvadą, kad turètų būti patobulinti atsinaujinančių energijos išteklių skatinimo mechanizmai siekiant nustatyti pagrịstas fiksuotas elektros energijos supirkimo iš atsinaujinan- čių energijos išteklių kainas bei kitas paramos formas. Dabartinès aukštos fiksuotos elektros energijos supirkimo iš atsinaujinančių energijos išteklių kainos Lietuvos gyventojams atrodo nepagrịstai aukštos ir jie yra pasirengę vidutiniškai moketi dvigubai mažesnes subsidijas už atsinaujinančius energijos išteklius. Labai svarbus yra gyventojų paramos bei visuomenès technologijų priimtinumo vertinimas bei darnių energetikos technologijų priimtinumo visuomeneje skatinimas [54].

Taigi, Lietuvoje atliktas PM už elektros energiją, pagamintą iš atsinaujinančių energijos išteklių, tyrimas parodè, kad pateikta informacija apie atsinaujinančius energijos išteklius, jų naudą ir paramos priemones turejo teigiamos įtakos gyventojų PM už elektros energiją, pagamintą iš atsinaujinančių energijos išteklių. Taip pat individualūs respondentai padidino savo PM už elektros energiją, pagamintą iš atsinaujinančių energijos išteklių, kai apie tai gavo informacijos. Taigi, informacijos sklaida yra veiksminga priemonė skatinant atsinaujinančių energijos išteklių panaudojimą namų ūkiuose, bei turi teigiamos įtakos naujų elektros energijos gamybos technologijų priimtinumui visuomenéje.

Atlikta apklausa parodè, kad užimtumas ir pajamos turi nemažai įtakos Lietuvos gyventojų PM už elektros energiją, pagamintą iš atsinaujinančių energijos išteklių. Savarankiškai dirbantys asmenys parode didžiausią PM už elektros energiją, pagamintą iš atsinaujinančių energijos išteklių. Be to, dirbantys privačiame sektoriuje ir pensininkai demonstravo didesnị nei vidutinis PM. Gyventojų lytis neturi įtakos PM už elektros energiją, pagamintą iš atsinaujinančiu energijos išteklių. Lyginant kitų PM už klimato kaitos švelninimo priemones studijų rezultatus galima teigti, kad tokie veiksniai, kaip aplinkosauginiai įsipareigojimai, informuotumas, išsilavinimo lygis ir pajamos, yra svarbūs, lemiantys PM už elektros energiją tiek Lietuvoje, tiek kitose šalyse, o amžius ir lytis didelès įtakos neturi.

Nustatyti pagrindiniai demografiniai bei socialiniai-ekonominiai veiksniai, lemiantys gyventojų PM už elektros energiją, pagamintą iš atsinaujinančių energijos išteklių, yra svarbūs formuojant atsinaujinančių energijos išteklių skatinimo politiką, nukreiptą ì namų ūkius. Būtini tolesni tyrimai siekiant nustatyti, kodèl 
atskiros gyventojų grupès pasižymi didesniu PM už elektros energiją, pagamintą iš atsinaujinančių energijos išteklių, bei taikyti diferencijuotas atsinaujinančių energijos išteklių skatinimo priemones skirtingose amžiaus, išsilavinimo, socialinio statuso grupèse.

\section{IŠVADOS}

1. Ekonomistai klimato kaitos švelninimo politikos naudą siūlo vertinti kaip kolektyvini visuomenès narių pasirengimą mokèti už klimato stabilizavimą. Kadangi išvengtą žalą dèl klimato kaitos politikos igyvendinimo labai sunku ịvertinti piniginiais vienetais, yra taikomas pasirengimo moketi (PM) metodas, skirtas nustatyti gyventojų preferenciją ir pasirengimą mokèti už klimato kaitos švelninimo priemones.

2. Yra du pagrindiniai metodai įvertinti PM: nustatytų ir pareikštų preferencijų metodai. Nustatytų preferencijų metodai siekia pasinaudoti rinkos teikiamais piniginiais naudos ịvertinimais taikant kelionès išlaidų ir hedonistinių kainų metodus, o pareikštų preferencijų metodai stengiasi nustatyti gyventojų PM taikant tiesiogines ir netiesiogines apklausas.

3. Visos išnagrinètos empirinès studijos, skirtos įvertinti gyventojų PM už klimato kaitos švelninimo priemones, kurių didžioji dauguma apėmè PM už atsinaujinančiu energijos išteklių tyrimus, taikè pareikštų preferencijų metodus: kontingento vertinimo metodą arba tiesioginę apklausą, nes nustatytų preferencijų metodai nèra tinkami klimato kaitos švelninimo politikos naudai vertinti dèl globalaus klimato kaitos pobūdžio.

4. Informacijos sklaida galètų būti veiksminga priemoné, skatinanti atsinaujinančių energijos išteklių panaudojimą bei tokių technologijų visuomenini priimtinumą, nes apklausos metu nustatyta, kad individualūs respondentai padidino savo PM už elektros energiją, pagamintą iš atsinaujinančių energijos išteklių, gavę informacijos apie atsinaujinančius energijos išteklius.

5. Ivairios demografinès bei socialinès-ekonominès charakteristikos skirtingai veikia gyventoju PM už atsinaujinančius energijos išteklius. Užimtumas ir pajamos turi nemažai itakos Lietuvos gyventojų PM už elektros energiją, pagamintą iš atsinaujinančiu energijos išteklių. Be to, tik gyventojai, turintys aukštąji išsilavinimą, parodè didesnị PM už elektros energiją, pagamintą iš atsinaujinančių energijos išteklių.

6. Respondentai, kurie informacinès kampanijos metu gavo papildomai žinių apie atsinaujinančius energijos išteklius, nusprendè, kad Vyriausybè yra atsakinga už atsinaujinančių energijos išteklių skatinimą, ir tai buvo viena svarbiausių priežasčių, stabdančių juos mokèti brangiau. Be to, jie buvo mažiau linkę aptarinèti atsinaujinančių energijos išteklių skatinimo problemas su draugais.

7. Tyrimo rezultatai parode, kad respondentai, kurie pasižymi didesniu nei vidutinis PM už elektros energiją, pagamintą iš atsinaujinančiu energijos išteklių, pripažista, kad atsinaujinančių energijos išteklių panaudojimas turi teigiamos itakos aplinkai ir švelnina klimato kaitą bei galvoja, kad atsinaujinančių energijos išteklių paramos kaštai turètų būti prisiimti visų visuomenès narių, iskaitant ir individualius energijos vartotojus. Be to, šiems respondentams kelia nerimą atsinaujinančių energijos išteklių skatinimo įtaka elektros energijos kainų augimui bei Lietuvos ekonominio augimo stabdymui. Todèl būtina tobulinti atsinaujinančių energijos išteklių skatinimo priemones peržiūrint fiksuotas elektros energijos, pagamintos iš atsinaujinančių energijos išteklių, supirkimo kainas bei teisingai paskirstant visiems visuomenėms nariams atsinaujinančių energijos išteklių paramos kaštus.

8. Atlikto Lietuvos gyventojų pasirengimo mokèti už atsinaujinančius energijos išteklius tyrimo rezultatai atitinka užsienyje atliktų studijų rezultatus. Lietuvoje atliktas tyrimas parodé, kad informacijos prieinamumas ir susirūpinimas aplinkos apsauga yra svarbūs veiksniai, lemiantys Lietuvos gyventojų pasirengimą mokèti už produktų inovacijas, susijusias su klimato kaitos švelninimu.

9. Lietuvos Vyriausybė turètų skirti daugiau dèmesio klimato kaitos politikos priemonèms, nukreiptoms ị vartojimo sektorių. Informacinès kampanijos, socialinè reklama visuomenès informavimo priemonèse bei kitos minkštos atsinaujinančių energijos išteklių skatinimo priemonès turetu teigiamos ittakos visuomenès nuomonei bei technologijų, naudojančių atsinaujinančius energijos išteklius, priimtinumui. Taip pat leistų tobulinti paramos atsinaujinantiems energijos ištekliams formas skatinant gyventojų pasirengimą 
mokèti už elektros energiją, pagamintą iš atsinaujinančių išteklių, ir taip užtikrinti prisiimtus politinius tikslus - didinti atsinaujinančių energijos išteklių panaudojimą.

10. Lietuvoje buvo pagristai sumažintos fiksuotų elektros energijos supirkimo iš atsinaujinančių energijos išteklių kainos, nes iki 2014 m. galiojusios subsidijos atsinaujinantiems ištekliams (aukščiausias elektros energijos supirkimo tarifas 1,66 Lt/kWh) buvo beveik dvigubai didesnès nei Lietuvos gyventojų PM už atsinaujinančius energijos išteklius, nustatytą $2013 \mathrm{~m}$. Šiuo metu (2014 m. II-IV ketv.) Lietuvoje aukščiausios fiksuotos supirkimo kainos neviršija $0,69 \mathrm{Lt} / \mathrm{kWh}$ ir yra mažesnès už Lietuvos gyventojų PM už $10 \%$ elektros energijos, pagamintos iš atsinaujinančių energijos išteklių (6,5 Lt arba 0,85 Lt/kWh), nustatytą tyrimo metu.

\section{PADE்KA}

Tyrimą finansuoja Lietuvos mokslo taryba (sutartis MIP-004/2012).

Gauta 20140403

Priimta 20140922

\section{LITERATŪRA}

1. Štreimikienė D., Baležentis T. Multi-objective ranking of climate change mitigation policies and measures in Lithuania. Renewable and Sustainable Energy Reviews. 2013. Vol. 18. P. 144-153.

2. Štreimikienė D., Baležentis T. Multi-criteria assessment of small scale CHP technologies in buildings. Renewable and Sustainable Energy Reviews. 2013. Vol. 26. P. 183-189.

3. European Commission. Directive 2009/28/EC on the Promotion of the Use of Energy from Renewable Sources and Amending and Subsequently Repealing Directives 2001/77/EC and 2003/30/EC. 2009.

4. Ministry of Energy of the Republic of Lithuania. Lithuanian National Renewable Action Plan 2010-2020. Vilnius, Lithuania, 2010.

5. Elektros energijos gamintojams, naudojantiems atsinaujinančius energijos išteklius, fiksuoti tarifai, ct/kWh (be PVM). 2014. http://www.regula. lt/atsinaujinantys-istekliai/Puslapiai/tarifai.aspx
6. Štreimikienė D., Mikalauskienė A. Willingness of Lithuanian households to pay for electricity produced from renewables. Proceedings of the 6th International Scientific Conference on Rural Development 2013, November 28-29, 2013, Akademija, Kaunas District, Lithuania. P. 372-382.

7. Adamowicz W., Louviere J., Williams M. Combining revealed and stated preference methods for valuing environmental amenities. Journal of Environmental Economics and Management. 1994. Vol. 26. No. 3. P. 271-292.

8. Samuelson P. A. The Pure Theory of Public Expenditure. Review of Economics and Statistics. 1954. Vol. 36. No. 4. P. 387-389.

9. Maddison D. J., Bigano A. The amenity value of the Italian climate. Journal of Environmental Economics and Management. 2003. Vol. 45. No. 2. P. 319-332.

10. Hotelling H. Letter to National Park Service. In: An Economic Study of the Monetary Evaluation of Recreation in the National Parks. Washington, DC: National Park Service, 1949.

11. Bell F. W. Recreational demand by tourists for saltwater beach days. Journal of Environmental Economics and Management. 1990. Vol. 18. No. 3. P. $189-205$.

12. Karasin L. The Travel Cost Method: Background, Summary, Explanation and Discussion. Discussion paper. Belgium: Centre for Economic and Social Studies on the Environment, l'Université Libre de Bruxelles, 1998.

13. Hensher D. A., Rose J. M., Greene W. H. Applied Choice Analysis: A Primer. Cambridge: Cambridge University Press, 2005.

14. Louviere J. J., Hensher D. A., Swait J. D. Stated Choice Methods: Analysis and Applications. Cambridge: Cambridge University Press, 2000.

15. Acito F., Jain A. K. Evaluation of conjoint analysis results: a comparison of methods. Journal of Marketing Research. 1980. Vol. 17. No. 1. P. 106-112.

16. Portiga W., Steg L., Vlek C., Wiersma G. Households preferences for energy saving measures: a conjoint analysis. Journal of Economic Psychology. 2003. Vol. 24. No. 1. P. 49-64.

17. Johnson E., Nemet G. F. Willingness to Pay for Climate Policy: Review of Estimates. Working paper No. 2010-011. La Follette School, 2010. 
18. Louviere J. J. Analyzing Decision Making. Metric Conjoint Analysis. Beverly Hills, CA: Sage, 1988. $95 \mathrm{p}$.

19. Luce R. D., Tukey J. W. Simultaneous conjoint measurement: a new type of fundamental measurement. Journal of Mathematical Psychology. 1964. Vol. 1. No. 1. P. 1-27.

20. Green P. E., Srinivasan V. Conjoint analysis in marketing: new developments with implications for research and practice. Journal of Marketing. 1990. Vol. 54. No. 4. P. 3-19.

21. Aravena C., Martinsson P., Scarpa R. Does money talk? The effect of a monetary attribute on the marginal rate of substitution in a choice experiment. Proceedings of the Third World Congress of Environmental and Resource Economists, July 3-7, 2006, Kyoto, Japan.

22. Banfi S., Farsi M., Filippini M., Jakob M. Willingness to pay for energy-saving measures in residential buildings. Energy Economics. 2008. Vol. 30. P. 503-516.

23. Bergmann A., Hanley N., Wright R. Valuing the attributes of renewable energy investments. Energy Policy. 2006. Vol. 34. No. 9. P. 1004-1014.

24. Ciriacy-Wantrup S. V. Capital returns from soil-conservation practices. Journal of Farm Economics. 1947. Vol. 29. No. 4. P. 1181-1196.

25. Mitchell R. C., Carson R. T. Using Surveys to Value Public Goods: The Contingent Valuation Method. Washington, DC, Baltimore: Johns Hopkins University Press, 1989. 463 p.

26. Bateman I. J., Willis K. G., Arrow K. J. Valuing Environmental Preferences: Theory and Practice of the Contingent Valuation Method in the US, EU, and Developing Countries. UK, Oxford: Oxford University Press, 1999. 645 p.

27. Herriges J. A., Shogren J. F. Starting Point Bias in Dichotomous Choice Valuation with Follow-Up Questioning. Journal of Environmental Economics Management. 1996. Vol. 30. No. 1. P. 112-131.

28. Stavins R. N. Environmental Economics. Working Paper 13547. Cambridge, MA: National Bureau of Economic Research, 2007.

29. Conner H. Taking non-monetizable impacts (NMIs) into account in an eco development strategy. In: O'Conner M., Spash M., Clive L. Valuation and the Environment. Northampton, Massachusetts, 1999. P. 241-262.
30. Cameron T. A. Individual option prices for climate change mitigation. Journal of Public Economics. 2005. Vol. 89. No. 2-3. P. 283-301.

31. Diaz-Rainey I., Ashton J. K. Characteristics of UK consumers' willingness to pay for green energy. Business Strategy and the Environment. 2007. Vol. 20. No. 7. P. 456-470.

32. Wiser R. Using contingent valuation to explore willingness to pay for renewable energy: a comparison of collective and voluntary payment vehicles. Ecological Economics. 2007. Vol. 62. No. 3-4. P. 419-432.

33. Hoyos D., Longo A., Markandya A. WTP for global and ancillary benefits of climate change mitigation: preliminary results. Proceedings of 17th Annual Conference of the European Association of Environmental and Resource Economists (EAERE), June 24-27, 2009, Amsterdam, The Netherlands. P. 24-27.

34. Ek K. Public and private attitudes towards "green" electricity: the case of Swedish wind power. Energy Policy. 2005. Vol. 33. No. 13. P. 1677-1689.

35. Longo A., Markandya A., Petrucci M. The internalisation of externalities in the production of electricity: willingness to pay for the attributes of a policy for renewable energy. Ecological Economics. 2006. Vol. 67. No. 1. P. 140-152.

36. Lutzenhiser L. Social and behavioural aspects of energy use. Annual Review of Energy and the Environment. 1993. Vol. 18. P. 247-289.

37. Allison M., Borchers J., Duke M., Parsons G. P. Does willingness to pay for green energy differ by source? Energy Policy. 2007. Vol. 35. No. 6. P. 3327-3334.

38. Duffy P., Hite D., Bransby D., Slaton C. Consumer willingness-to-pay for green energy: results from focus groups. Selected Paper at the Annual Meeting of the Southern Agricultural Economics Association Mobile, February 4-7, 2007, Alabama, USA. P. 1-18.

39. Scarpa R., Willis K. Willingness-to-pay for renewable energy: primary and discretionary choice of British households for micro-generation technologies. Energy Economics. 2010. Vol. 32. No. 1. P. 129-136.

40. Viscusi W., Zeckhauser R. The perception and valuation of the risks of climate change: a rational and behavioral blend. Climatic Change. 2006. Vol. 77. No. 1-2. P. 151-177. 
41. Solomon B. D., Johnson N. H. Valuing climate protection through willingness to pay for biomass ethanol. Ecological Economics. 2009. Vol. 68. No. 7. P. 2137-2144.

42. Portiga W., Steg L., Vlek C. Environmental concern and environmental behavior: a study into household energy use. Environment and Behaviour. 2004. Vol. 36. No. 1. P. 70-93.

43. Brouwer R., Brander L., Van Beukering P. A convenient truth: air travel passengers' willingness to pay to offset their $\mathrm{CO}_{2}$ emissions. Climatic Change. 2008. Vol. 90. No. 3. P. 299-313.

44. Bohringer C., Vogt C. Economic and environmental impacts of the Kyoto Protocol. The Canadian Journal of Economics. 2003. Vol. 36. No. 2. P. 475-496.

45. Berk R. A., Fovell R. G. Public perceptions of climate change: A 'Willingness to Pay' Assessment. Climatic Change. 1999. Vol. 41. No. 3-4. P. 413446.

46. Berrens R. P., Bohara A. K., Jenkins-Smith H., Silva C. S., Weimer D. W. Information and effort in contingent valuation surveys: Application to global climate change using national internet samples. Journal of Environmental Economics and Management. 2004. Vol. 47. No. 2. P. 331363.

47. Akter S., Bennett J. Household perceptions of climate change and preference for mitigation action: the case of the Carbon Pollution Reduction Scheme in Australia. Proceedings of 53rd Annual Conference of the Australian Agricultural and Resource Economics Society, February 11-13, 2009, Cairns, Australia.

48. Achtnicht M. German Car Buyers' Willingness to Pay to Reduce $\mathrm{CO}_{2}$ Emissions. Discussion Paper No. 09-058. ZEW (Centre for European Economic Research), 2009.

49. Li H., Berrens R., Bohara A., Jenkins-Smith H., Silva C., Weimer D. Would developing country commitments affect US households' support for a modified Kyoto Protocol? Ecological Economics. 2004. Vol. 48. No. 3. P. 329-343.

50. Carlsson F., Kataria M., Krupnick A., Lampi E., Lofgren A., Qin P., Chung S., Sterner T. Paying for mitigation: A multiple country study. Land Economics. 2010. Vol. 88. No. 2. P. 326-340.
51. Yoo S., Kwak S. Willingness to pay for green electricity in Korea: A contingent valuation study. Energy Policy. 2009. Vol. 37. No. 12. P. 54085416.

52. Nomura N., Akai M. Willingness to pay for green electricity in Japan as estimated through contingent valuation method. Applied Energy. 2004. Vol. 78. No. 4. P. 453-463.

53. Hayfield T., Racine J. S. Nonparametric Econometrics: The Nonparametric Package. Journal of Statistical Software. 2008. Vol. 27. No. 5. P. 1-32.

54. Štreimikienė D., Baležentis T., Kriščiukaitienė I. Promoting interactions between local climate change mitigation, sustainable energy development, and rural development policies in Lithuania. Energy Policy. 2012. Vol. 50. P. 699-710.

\section{Dalia Štreimikienė, Ilona Ališauskaitė-Šeškienẻ \\ ASSESSMENT OF WILLINGNESS TO PAY FOR RENEWABLES IN LITHUANIA}

\section{Summary}

There are many forms of support for renewable energy in Lithuania, but all of them focus on the manufacturing sector, while the world focuses on the demand sector and there are many papers dealing with the social assessment of new technologies and the social acceptability of technologies by consumers. Since 1st of January 2013 Lithuanian residents are free to choose their electricity supplier and also support the use of renewable energy resources, that is why it is important to investigate the consumers' willingness to pay for electricity from renewable energy sources in Lithuania and to identify the key factors that determine the preparation of the population to pay for electricity from renewable energy sources.

The purpose of this article is to carry out the assessment of Lithuanian population willingness to pay for renewable energy resources and to compare achieved results with studies performed in other countries.

Key words: renewable energy, consumer willingness to pay, the energy sector, the assessment 
Даля Штреймикене, Илона Алишаускайте-

Шешкене

ОЦЕНКА ГОТОВНОСТИ ПЛАТИТЬ ЗА

ВОЗОБНОВЛЯЕМЫЕ ИСТОЧНИКИ ЭНЕРГИИ В ЛИТВЕ

Резюме

Есть много форм поддержки возобновляемой энергетики в Литве, но все они сосредоточены на производственном секторе, в то время как весь мир сконцентрировался на спрос и оценке социальной приемлемости технологий, а также на исследование поведения потребителей. Хотя с 1 января 2013 жители Литвы могут свободно выбирать поставщика электроэнергии, а также поддержать использование возобновляемых источников энергии, многие люди даже не знают о такой возможности. В этой связи важно исследовать готовность потребителей платить за электричество из возобновляемых источников энергии в Литве и определить основные факторы, определяющие готовность населения платить за электричество из возобновляемых источников энергии. Цель этой статьи заключается в проведении оценки готовность потребителей платить за электричество из возобновляемых источников энергии в Литве и сравнить полученные оценки с результатами исследований, проведенных в других странах.

Ключевые слова: возобновляемые источники энергии, готовность потребителей платить, энергетический сектор, оценка 